\title{
in Science \\ through time and space
}

\author{
Жамият ва инновациялар - \\ Общество и инновации - \\ Society and innovations \\ Journal home page: \\ https://inscience.uz/index.php/socinov/index
}

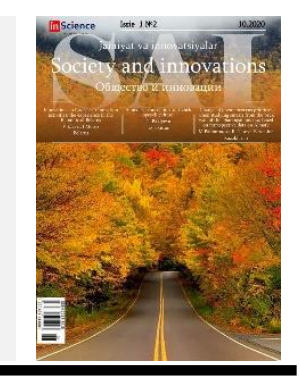

\section{Judicial protection of exclusive rights to intellectual property: national and foreign experience}

\section{Khoji-Murod ISOQOV ${ }^{1}$}

Judicial Council of the Republic of Uzbekistan

\begin{tabular}{l} 
ARTICLE INFO \\
\hline Article history: \\
Received September 2020 \\
Received in revised form \\
15 September 2020 \\
Accepted 15 October 2020 \\
Available online \\
30 October 2020
\end{tabular}

Keywords:

judicial protection, intellectual law intellectual property dispute.

\section{ABSTRACT}

The article examines national and foreign experience in judicial protection of exclusive rights to intellectual property. The role and specificity of judicial protection, the legal framework regulating this sphere, the effectiveness of national legislation, relevance to the judiciary, judicial statistics in this matter, case law and the experience of foreign countries are analyzed in order to come up with the methods of protection of exclusive rights to intellectual property.

The socio-economic and legal consequences of the settlement of intellectual property disputes are presented as one of the most pressing issues in the work of the courts in the light of the fact that the issue of intellectual property rights is becoming a serious social problem in Uzbekistan and all around the world.

Based on in-depth analysis of the world experience on how the issue of jurisdiction of intellectual property cases is resolved, it is concluded that the establishment of separate courts specializing specifically in intellectual property disputes will result in resolving disputes without delay in a fair and reasonable manner.

The article differentiates between two categories of problems in the consideration of intellectual property issues in court practice. The first type of problems is related to subjective factors, while the second is demonstrated to comprise objective difficulties. Subjective problems comprise of the courts lacking the experience to resolve all disputes involving intellectual property rights. Alternatively, the objective factors are stated to entail the lack of clear legal framework or underdevelopment of single court practice regulating this category of cases.

Therefore, it is concluded that the establishment of specialized courts in Uzbekistan specifically dealing with intellectual property disputes is justified by the development of social relations based on a market economy and the growing

\footnotetext{
${ }^{1}$ DSc, professor, Supreme School of Judges under the Supreme Judicial Council of the Republic of Uzbekistan, Tashkent, Uzbekistan
} 
importance of intellectual property in the life of the state and society. In this regard, it is argued that the process of formation of a panel of judges in the Supreme Court of the Republic of Uzbekistan should entail a system of retraining and advanced training of judges in the field of intellectual property rights in cooperation with the World Intellectual Property Organization and the Intellectual Property Agency.

Taking comparative research methods as a basis, it is suggested that the Civil Procedural Code of the Republic of Uzbekistan, the Economic Procedural Code of the Republic of Uzbekistan, the Code of the Republic of Uzbekistan on Administrative offences should include a chapter devoted to reflection of the specifics of litigation of intellectual property rights, claims, lawsuits, deadlines for appeals and other procedural deadlines, norms that cover all aspects of such disputes differentiating them from other types of cases, as well as, the issue of developing the norms regulating the administrative liability for offences in the field of intellectual property rights and the criminal liability for illegal use of intellectual property rights is also justified.

2181-1415/CC 2020 in Science LLC.

This is an open access article under the Attribution 4.0 International (CC BY 4.0) license (https://creativecommons.org/licenses/by/4.0/deed.ru)

\section{Интеллектуал мулк объектларига нисбатан мутлақ хуқуқларни суд орқали химоя қилиш: миллий ва хорижий тажриба}

Калит сўзлар:
суд мухофазаси,
интеллектуал қонун
интеллектуал мулк
низо.

\section{АННОТАЦИЯ}

Мақолада интеллектуал мулк объектларига нисбатан мутлақ хуқуқларни суд орқали химоя қилиш борасидаги миллий ва хорижий тажриба ўрганилган. Интеллектуал мулк объектларига нисбатан мутлақ хуқуқларни мухофаза қилиш усуллари ичида суд орқали химоя қилишнинг ўрни ва ўзига хослиги, мазкур масаланинг хуқуқий асослари, миллий қонунчилик ахволи, судловга тааллуқлилиги, бу борадаги суд статистикаси, суд амалиёти хамда хорижий давлатлар тажрибаси тахлил қилинган.

Бугунги кунда интеллектуал мулк объектлари билан боғлиқ бўлган низоларни хал этиш масаласи судлар фаолиятидаги энг долзарб масалалардан бири эканлиги, чунки интеллектуал мулк хуқуқларининг бузилиши мавзуси бутун дунёда бўлгани каби Ўзбекистонда хам жиддий ижтимоий муаммога айланиб бораётганлиги эътироф этилган холда унинг ижтимоий-иқтисодий ва хукуқий оқибатлари асослаб берилган.

Жахон мамлакатлари тажрибасида интеллектуал мулк объектлари билан боғлиқ ишларнинг судловга 
тааллуқлилиги масаласи қандай хал этилганлигини чуқур тахлил қилиш асосида интеллектуал мулк объектлари билан боғлиқ низоларни кўришга ихтисослашган алоқида судларнинг ташкил этилиши низоларни сансалорликларсиз, қисқа муддатларда кўриб чиқилишига хамда қонуний, асосли ва адолатли суд қарорлари қабул қилинишига замин яратиши тўғрисида хулосага келинган.

Мақолада судлар амалиётида интеллектуал мулк билан боғлиқ масалаларни кўриб чиқишда асосан икки тоифадаги муаммо мавжудлиги таъкидланган. Биринчиси, субъектив омиллар билан боғлиқ бўлса, иккинчиси, объектив қийинчилар эканлиги кўрсатилган. Субъектив муаммолар қаторида судларда мазкур тоифадаги ишларнинг барчасини хам кўриб хал этиш бўйича тажрибанинг мавжуд эмаслиги айтилган. Объектив омиллар сифатида судлар томонидан ушбу тоифадаги ишларни кўриб чиқишда муайян хуқуқий асоснинг мавжуд эмаслиги ёхуд тегишли қонун хужжатларининг лозим даражада такомиллашмаганлиги, шу боис, бу борада ягона суд амалиётининг шаклланмаганлиги эътироф этилган.

Бозор иқтисодиётига асосланган ижтимоий муносабатларнинг тобора ривожланиши, интеллектуал мулкнинг давлат ва жамият хаётидаги ахамияти ва ўрнининг кескин ошиб бораётганлиги Ўзбекистонда хам ителлектуал мулк билан боғлиқ низоларни кўриб чиқишга ихтисослашган судларни ташкил этиш заруратини келтириб чиқараётганлиги хақида хулоса қилинган. Шу сабабли, Ўзбекистон Республикаси Олий судида интеллектуал мулк билан боғлиқ низоларни кўришга ихтисослашган судлов хайъатини ташкил этиш мақсадга мувофиқлиги асосланган. Шунингдек, Ўзбекистон Республикаси Судьялар олий кенгаши хузуридаги Судьялар олий мактабида судьяларни интеллектуал мулк хуқуқига доир низоларни кўриш бўйича қайта тайёрлаш ва малакаларини ошириш тизимини йўлга қўйиш хамда бу борада Бутунжахон интеллектуал мулк ташкилоти ва Интеллектуал мулк агентлиги билан хамкорликни ривожлантириш лозимлиги таъкидланган.

Қиёсий тадқиқот усуллари асосида Ўзбекистон Республикасининг Фуқаролик процессуал кодекси, Иқтисодий процессуал кодекси, Маъмурий суд ишларини юритиш тўғрисидаги кодексига интеллектул мулк хуқуқига оид низоларни судда кўришнинг ўзига хос хусусиятларини акс эттирувчи нормаларни жамлаган боб киритиш, ушбу бобда даъво аризалари, аризалар, шикоятларга қўйиладиган талаблар, судга мурожаат қилиш муддатлари ва уларни кўриб чиқишнинг процессуал муддатлари, бу турдаги ишларни кўришнинг бошқа тоифадаги ишлардан фарқли бўлган жихатларини ёритиб берувчи барча холатларни ифодаловчи нормаларни назарда тутиш, 
интеллектуал мулк хуқуқи сохасидаги маъмурий хуқуқбузарликлар учун маъмурий жавобгарликни, шунингдек интеллектуал мулк объектларидан ноқонуний фойдаланганлик учун жиноий жавобгарликни кучайтириш масалаларини хам кўриб чиқиш зарурлиги исботлаб берилган..

\section{Судебная защита исключительных прав на интеллектуальную собственность: национальный и зарубежный опыт}

\author{
Ключевые слова: \\ судебная защита, \\ интеллектуальное право \\ интеллектуальная \\ собственность \\ спор.
}

\section{АННОТАЦИЯ}

В статье исследуется национальный и зарубежный опыт судебной защиты исключительных прав на интеллектуальную собственность. Анализируются роль и специфика судебной защиты как средства охраняющего исключительные права на объекты интеллектуальной собственности, состояние национального законодательства, регулирующего эту сферу, подсудность и судебная статистика касаемо исследуемых аспектов, а также судебная практика и опыт зарубежных стран.

Акцентируя что на сегодняшний день вопрос нарушения прав интеллектуальной собственности становится существенной социальной проблемой по всему миру, а также и в Узбекистане, в виду его социально-экономических последствий, обосновано мнение о наиболее актуальности судебного разрешения споров, связанных с объектами интеллектуальной собственности.

На основе глубокого анализа опыта зарубежных стран касаемо вопроса подсудности дел, связанных с интеллектуальной собственностью сделаны заключения о том, что создание отдельных судов, специализированных на рассмотрение споров, связанных с объектами интеллектуальной собственности, послужит разрешению данных споров в кротчайшие сроки, без допущения излишней волокиты, а также вынесению законных, обоснованных и справедливых судебных решений.

В статье отмечается, что при рассмотрении споров, связанных с объектами интеллектуальной собственности, как правило, существуют 2 категории проблем. Первая проблема обусловлена субъективными факторами, а вторая - объективными. В качестве объективных факторов отмечаются отсутствие определенного правового основания для рассмотрения подобной категории дел либо несовершенство действующего законодательства, в следствии чего, не сформирована единая судебная практика. 
Обосновано, что создание специализированных судов в Узбекистане по разрешению споров в области интеллектуальной собственности обусловлено развитием общественных отношений, основанных на рыночной экономике и стремительным ростом значимости интеллектуальной собственности в жизни государства и общества.

Аргументировано предложение о необходимости формирования специализированной судебной коллегии в Верховном суде Республики Узбекистан, а также о налаживании практики переподготовки и повышения квалификации судей в области прав интеллектуальной собственности, сотрудничестве с Всемирной организацией интеллектуальной собственности и Агентством интеллектуальной собственности.

На основе сравнительных методов исследования, предлагается включить в Гражданский процессуальный кодекс Республики Узбекистан, Экономический процессуальный кодекс Республики Узбекистан, Кодекс Республики Узбекистан об административной ответственности соответствующие главы, устанавливающие процедуру судебного разрешения споров, связанных с правами интеллектуальной собственности.

Дунёнинг хар қандай мамлакати каби Ўзбекистон учун хам бугунги кунда интеллектул мулк хуқуқи мухофазасини таъминловчи ташкилий-хуқуқий механизмларни такомиллаштириш энг долзарб масалалардан бири бўлиб хисобланади. Бинобарин, халқаро хуқуқий хужжатларда хам миллий қонунчилигимизда хам интеллектуал мулк объектларига нисбатан мутлақ хуқуқлар ўта мухим фуқаролик хуқуқларидан бири сифатида тан олинади. Хар бир инсон ўзи муаллифи хисобланган илмий, адабий ва бадиий фаолият натижаларига нисбатан маънавий ва моддий манфаатлари мухофаза қилинишини талаб қилиш хуқуқига эгадир.

Интеллектуал мулк объектларига нисбатан мутлақ хуқуқларни химоя қилиш усуллари Ўзбекистон Республикасининг Фуқаролик кодекси(бундан буён ФК деб юритилади)нинг 1040-моддасида белгиланган. Унга кўра интеллектуал мулк объектларига нисбатан мутлақ хуқуқларни химоя қилиш ФКнинг 11-моддасида назарда тутилган усуллар билан амалга оширилади. Мутлақ хуқуқларни химоя қилиш шунингдек:

мутлақ хуқуқлар қайси моддий объектлар ёрдамида бузилган бўлса, ўша моддий объектларни хамда бундай бузиш натижасида яратилган моддий объектларни олиб қўйиш орқали;

йўл қўйилган бузиш хақидаги маълумотни мажбурий суратда эълон қилиб, унга бузилган хуқуқ кимга тегишлилиги тўғрисидаги маълумотларни киритиш орқали;

қонунда назарда тутилган бошқа усулларда амалга оширилиши мумкин. 
Интеллектуал фаолият натижаларини ва хусусий аломатларни акс эттирувчи воситаларни яратиш хамда улардан фойдаланиш тўғрисидаги шартнома бузилганда мажбуриятларни бузганлик учун жавобгарлик тўғрисидаги умумий қоидалар қўлланилади [1].

ФКнинг 11-моддасида назарда тутилган фуқаролик хуқуқларини химоя қилиш усулларининг рўйхатидан келиб чиқиб айтадиган бўлсак, шахснинг интеллектуал мулк объектларига нисбатан мутлақ хуқуқлари қуйидаги йўллар билан химоя қилинади: хуқуқни тан олиш; хуқуқ бузилишидан олдинги холатни тиклаш ва хуқуқни бузадиган ёки унинг бузилиши хавфини туғдирадиган харакатларнинг олдини олиш; битимни хақиқий эмас деб топиш ва унинг хақиқий эмаслиги оқибатларини қўллаш; давлат органининг ёки фуқароларнинг ўзини ўзи бошқариш органининг хужжатини хақиқий эмас деб топиш; шахснинг ўз хуқуқини ўзи химоя қилиши; бурчни аслича (натура) бажаришга мажбур қилиш; зарарни тўлаш; неустойка ундириш; маънавий зиённи қоплаш; хуқуқий муносабатни бекор қилиш ёки ўзгартириш; давлат органининг ёки фуқароларнинг ўзини ўзи бошқариш органининг қонунга зид хужжатини суднинг қўлламаслиги.

Интеллектуал мулк объектларига нисбатан мутлақ хуқуқларни қонунда назарда тутилган бошқа усуллар билан хам химоялашга йўл қўйилади. Бир пайтнинг ўзида интеллектуал мулк объектларига нисбатан мутлақ хуқуқларни химоя қилишнинг бир неча усулини қўллаш истисно қилинмайди. Фавқулодда холатларда, қонунчилик талаблари юзасидан ёки бузилган (даъво қилинган) хуқуқнинг хусусиятидан келиб чиқиб, у фақат муайян усул билан химоя қилиниши лозим. Интеллектуал мулкка доир хуқуқларни химоялашнинг усуллари, мазкур усулларни амалга ошириш механизмига боғлиқ равишда бўлиниши мумкин: 1) фақат суд томонидан, айрим холатларда эса бошқа ваколатли давлат органлари томонидан қўлланадиган усуллар. Бу эса муайян усул воситасида химоя қилиш тўғрисида уларга илтимоснома билан мурожаат қилиш заруратини назарда тутади (хуқуқни тан олиш, хуқуқ бузилгунига қадар мавжуд бўлган холатни тиклаш, хуқуқни бузувчи харакатларни тўхтатиш ва х.); 2) хуқуқий муносабат иштирокчиси томонидан мустакил равишда қўлланадиган усуллар (ўз-ўзини химоялаш, қонунда ёки шартномада назарда тутилган бўлса, мажбуриятларни бажаришдан бир томонлама воз кечиш йўли билан хуқуқий муносабатларни бекор қилиш ва б.); 3) хам суд органларининг ёрдами билан, хам мустақил тартибда қўлланадиган усуллар (зарарни қоплаш, неустойка ундириш ва б.).

Интеллектуал мулк объектларига нисбатан мутлақ хуқуқларни мухофаза қилиш усуллари ичида суд орқали химоя қилиш мухим ўрин эгаллайди ва у қонун билан кафолатланади. Чунончи, Ўзбекистон Республикаси Конституциясининг 44моддасига биноан хар бир шахсга ўз хуқуқ ва эркинликларини суд орқали химоя қилиш, давлат органлари, мансабдор шахслар, жамоат бирлашмаларининг ғайриқонуний хатти-харакатлари устидан судга шикоят қилиш хуқуқи кафолатланади [2].

Тахлиллардан аён бўладики, мамлакатимиз судларида кўрилаётган интеллектуал мулк билан боғлиқ ишлар сони йилдан йилга ортиб бормоқда (масалан, 2011 йилда суд органлари томонидан интеллектуал мулк объектлари ва уларга оид хуқуқларни таъминлашга алоқадор 22 иш куирилган бўлса, 2018 йилда бу курсаткич 100 дан ошган) [3]. 
Ушбу кўрсатгичлар мамлакатимизда кундан кунга фан, техника, санъат ривожланиб келаётганлиги, интеллектуал мулк эгаларининг эса ўзларининг интеллектуал мулкига бўлган хуқуқларини суд тартибида химоя қилиш билан боғлиқ мурожаатларининг сони ва турлари ортиб бораётганлигидан дарак.

Қонунчилигимизга асосан интеллектуал мулк объектларига доир ишларни кўриб чиқиш уларнинг тоифасидан келиб чиққан холда деярли барча судларнинг судловига тааллуқли бўлиши мумкин. Бироқ, масаланинг хуқуқий табиати инобатга олинадиган бўлса, интеллектуал мулк объектларига доир хуқуқлар суд орқали асосан фуқаролик хуқуқий муносабатлари доирасида химоя қилиниши лозим деган хулосага келиш мумкин. Шунингдек, агарда, интеллектуал мулк объектларига доир низо “Хакамлик судлари тўғрисида”ги Ўзбекистон Республикаси Қонунининг 12-моддаси талабларига мувофиқ тартибда тузилган битим билан боғлиқ бўлса, бундай низоларни хал этилиши хакамлик судларига топширилиши хам мумкин.

Хусусан, 2018, 2019 йиллар ва 2020 йилнинг биринчи чораги давомида судлар томонидан кўрилган ишлар юзасидан статистик тахлилларга назар ташласак қуйидаги холатнинг гувохи бўламиз.

Фуқаролик ишлар бўйича судлар томонидан 2018 йилда интеллектуал мулк хуқуқи билан боғлиқ низолар бўйича жами 8 та иш кўриб тамомланган. Шундан, 2 таси қаноатлантирилган, 3 таси рад этилган, 2 таси бўйича иш юритиш тугатилган ва 1 таси кўрмасдан қолдирилган. 2019 йилда жами 6 та иш кўриб тамомланган, шундан 2 таси қаноатлантирилган, 3 таси рад этилган ва қолган 1 таси кўрмасдан қолдирилган. 2020 йилнинг биринчи чорагида жами 1 та иш кўриб тамомланган ва у қаноатлантирилган.

Маъмурий судлар томонидан интеллектуал мулк хуқуқи бўйича (хуқуқбузарликлар юзасидан) Маъмурий жавобгарлик тўғрисидаги кодекснинг $177,177^{1}$ ва $177^{2}$-моддаларини қўллаган холда маъмурий ишлар кўриб чиқилган. 2018 йилда маъмурий судлар томонидан МЖтКнинг 177-моддаси бўйича 2 та иш 2 нафар шахсга нисбатан кўриб тамомланган. 2019 йилда МЖтКнинг 177-моддаси бўйича жами 7 та иш 11 нафар шахсга нисбатан кўриб тамомланган. 2018 йилда МЖтКнинг 1771-моддаси бўйича иш кўрилмаган. 2019 йилда МЖтКнинг 1771-моддаси бўйича 8 та иш 8 нафар шахсга нисбатан кўриб тамомланган бўлса, шундан 2 та иш бўйича 2 нафар шахсга нисбатан жарима жазоси тайинланган, қолган 6 нафар шахсга нисбатан 6 та иш тугатилган. 2018, 2019 йиллар ва 2020 йилнинг биринчи чораги давомида хам МЖтКнинг 1772-моддаси бўйича иш кўрилмаган. 2020 йилнинг биринчи чораги давомида МЖтКнинг 177 ва 1771 моддалари бўйича 1 та иш 1 нафар шахсга нисбатан кўриб тамомланган.

Мисол учун, «Ўзбеккино» Миллий агентлиги Ўзбекистон Республикаси Муаллифлик хуқуқлари ва турдош хуқуқларни химоя қилиш жамияти билан биргаликда веб-ресурс устидан судга даъво аризаси билан мурожаат қилган. Аризага кўра, 1983 йилда туғилган фуқаро Ж.И. миллий фильмларни ноқонуний тарқатиш билан шуғулланиб келган. Мазкур иш Қўқон шахар маъмурий суди томонидан кўриб чиқилиб, Ўзбекистон Республикаси Маъмурий жавобгарлик тўғрисидаги кодекснинг 1771-моддасига биноан фуқаро Ж.И. нисбатан маъмурий жавобгарлик чоралари қўлланилган [4]. 
Маъмурий судлар томонидан (оммавий-хуқуқий муносабат буйича) 2018 йилда 17 та иш кўриб тамомланган. Шундан, 5 таси қаноатлантирилган, 11 таси рад этилган ва 1 таси буйича иш юритишдан тугатилган. 2019 йилда эса, 19 та иш кўриб тамомланган. Шундан, 7 таси қаноатлантирилган, 9 таси рад этилган ва 3 таси бўйича иш юритишдан тугатилган. 2020 йилнинг биринчи чораги давомида бу тоифадаги ишлар кўриб чиқилмаган. Эътиборли холатлардан бири шуки, юқорида қайд этилган статистик маълумотларида назарда тутилган оммавий-хуқуқий муносабатлардан келиб чиқувчи маъмурий ишларнинг барчаси фақатгина Тошкент шахрида фаолият кўрсатувчи маъмурий судлар томонидан кўриб чиқилган. Бошқа худудлардаги маъмурий судлар томонидан биронта хам оммавий-хуқуқий муносабат бўйича иш кўрилмаган.

Иқтисодий судлар томонидан интеллектуал мулк хуқуқи буйича 2018 йилда жами 63 та иш кўриб тамомланган. Шундан 17 таси фирма номига бўлган хуқуқдан келиб чиққан низолар бўлса, 46 таси товар белгилари (хизмат кўрсатиш белгиси)га бўлган хуқуқдан келиб чиққан низолардир. Фирма номига бўлган хуқуқдан келиб чиққан низолар бўйича жами кўрилган 17 та ишлардан 12 таси бўйича даъво талаблари қаноатлантирилган, 2 таси бўйича рад этилган, 2 та иш кўрмасдан қолдирилган, 1 таси иш юритишдан тугатилган ва қолган 1 таси ўзаро келишув битими асосида тугатилган. Товар белгилари (хизмат кўрсатиш белгиси)га бўлган хуқуқдан келиб чиққан низолар юзасидан жами кўрилган 46 та ишлардан 21 таси бўйича даъволар қаноатлантирилган, 11 таси бўйича рад этилган, 2 та иш кўрмасдан қолдирилган, 12таси иш юритишдан тугатилган ва қолган 3 таси ўзаро келишув битими асосида тугатилган. 2019 йилда жами 28 та иш кўриб тамомланган. Шундан 17 таси бўйича қўйилган талаб қаноатлантириган, 7 таси бўйича рад этилган, 1 та иш кўрмасдан қолдирилган ва 3 таси бўйича иш юритиш тугатилган. 2020 йилнинг беш ойи бўйича жами 15 та иш кўриб тамомланган. Шундан 7 таси бўйича қўйилган талаб қаноатлантириган, 7 таси бўйича рад этилган, 1 та иш кўрмасдан қолдирилган ва 2 таси бўйича иш юритиш тугатилган.

Статистик тахлилларга қараганда, иқтисодий судлар томонидан интеллектуал мулк хуқуқи бўйича товар белгилари (хизмат кўрсатиш белгиси)га бўлган хуқуқдан келиб чиққан низолар кўпроқ кўрилган. Хаммага маълум товар белгилари низоларининг судлар томонидан кўриб чиқиш ва мухофаза қилиш масалаларини ўрганган холда амалдаги қонунчиликдаги мавжуд қоидаларни хаммага маълум товар белгиларининг хуқуқий мақомидан келиб чиқиб, халқаро қонунчилик талаблари даражасида такомиллаштириш лозимгини таъкидламоқчимиз. Жумладан, хаммага маълум товар белгилари хуқуқий мухофаза қилинишини таъминлашда контрафакт махсулот ишлаб чиқарувчиларнинг таъсир доирасига тушиб қолишидан асраш мақсадида қуйидагиларга алохида эътибор қаратиш лозим:

- товар бозорида контрафакт махсулотларга нисбатан талаб ва таклиф даражасини маркетинг тадқиқоти сифатида доимий мониторинг ишларини амалга ошириш;

- тегишли худудда жойлашган бозор маъмурияти томонидан хуқуқни мухофаза қилувчи органларга контрафакт махсулотларни чакана ва улгуржи савдо қилувчи сотиб олувчи, сотувчи ва ишлаб чиқарувчилар тўғрисида доимий ахборот маълумотларини жамлаш ва тегишли органга тақдим этиб бориш; 
- истеъмолчилар оммасини маълум товар белгиси остида ишлаб чиқарилган контрафакт товар махсулотлар тўғрисида оммавий ахборот воситалари орқали доимий равишда маълумот бериб бориш. Контрафакт махсулотлар тўғрисида телевиденияда махсус дастур фаолиятини йўлга қўйиш;

- хаммага маълум товар белгиларини хуқуқий мухофаза қилиш билан боғлиқ қонун хужжатларида белгиланган жавобгарлик чораларини алохида хаммага маълум товар белгисидан фойдаланиш қоидаларини бузганлик нуқтаи назаридан қайта кўриб чиқиш. Шунингдек, маъмурий ва жиноий жавобгарлик тўғрисидаги қонун хужжатларини такомиллаштиришга алохида эътибор қаратиш лозим.

Шу ўринда интеллектуал мулк объектларига нисбатан мутлақ хуқуқларнинг суд орқали химоя қилинишига доир бир мисолга муфассалроқ тўхталишни лозим топдик.

Даъвогар “Societe des Produits Nestle S.A" компанияси жавобгар "Family Group" МЧЖ ҚКга нисбатан иқтисодий судга даъво аризаси билан мурожаат қилган. Даъвогарнинг фикрича унинг мутлақ хуқуқлари жавобгар томонидан бузиб келинган ва бу истеъмолчиларни ўзи томонидан ишлаб чиқарилаётган махсулотнинг сифати хамда ишлаб чиқарувчиси тўғрисида чалғитиши оқибатида унга зиён етказиши мумкин. Чунончи, жавобгар томонидан ичимлик сувини ишлаб чиқаришда, реклама қилишда ва тасарруф қилишда фойдаланилаётган товар белгиси, яъни қўллари юқорига кўтарилган одамлар тасвири (силуэти) ва марказдан таралаётган кўк-мовий нурлар фонидаги айлана график қисмлардан (элементлардан) иборат кўринишдаги марка истеъмолчини янглишувга олиб келувчи даражада ўзининг товар белгисига айнан ўхшашлигини важ қилиб, жавобгарга ундан фойдаланишни тўхтатиш мажбуриятини юклашни сўраган. Суднинг ажрими билан ишга мустақил талаблар билан арз қилмайдиган учинчи шахс сифатида Ўзбекистон Республикаси Интеллектуал мулк агентлиги жалб қилинган.

Суд жараёнида аниқланишича, даъвогар “Societe des Produits Nestle S.A" компанияси ўзининг товар белгисини Ўзбекистон Республикасида товар белгиларини химоя қилиш учун халқаро рўйхатдан (№ 867993-сонли 26.09.2014 йилда, № 695660-сонли 01.07.1998 йилда, № 941054-сонли 21.09.1997 йилда ва № 895614-сонли 29.06.2006 йилда) ўтказган.

Белгиларни рўйхатдан ўтказиш бўйича товарлар ва хизматларнинг халқаро таснифига мувофиқ иккала юридик шахс томонидан ишлаб чиқарилган махсулотлар ўхшаш ва бир хил мақсадга эга.

Ўзбекистон Республикасининг “Товар белгилари, хизмат кўрсатиш белгилари ва товар келиб чиққан жой номлари тўғрисида”ги Қонунининг 3-моддасига асосан товар белгиси ва хизмат кўрсатиш белгиси (бундан буён матнда товар белгиси деб юритилади) бу бир юридик ва жисмоний шахслар товарлари ва хизматларини (бундан буён матнда товарлар деб юритилади) бошқа юридик ва жисмоний шахсларнинг шу турдаги товарларидан фарқлаш учун хизмат қиладиган, белгиланган тартибда рўйхатдан ўтказилган белгилардир.

Ўзбекистон Республикаси Давлат патент идораси директорининг “Товар белгиси ва хизмат кўрсатиш белгисини рўйхатдан ўтказиш учун талабнома тузиш, топшириш ва кўриб чиқиш қоидаларини тасдиқлаш тўғрисида"ги буйруғи ( Ч̆збекистон Республикаси Адлия вазирлиги томонидан 2009 йил 29 июлда 1988- 
сон билан давлат рўйхатидан ўтказилган)га асосан ўхшашлик сўзли белгиларнинг ўхшашлиги, товушли ўхшашлик, график ўхшашлик, мазмунан ўхшашлик ва жамлама белгининг ўхшашлик каби кўринишларда бўлиши мумкин. График ўхшашлик қуйидаги аломатлар а) умумий кўриш таассуроти; б) шрифт тури; в) харфлар характерини хисобга олган холда график ёзилиши (босма ёки ёзма, бош ёки кичик харф); г) харфларнинг бир-бирига нисбатан жойлашиши; д) сўз харфлари ёзилган алифбо; е) ранг ёки ранглар уйғунлиги асосида аниқланади.

2015 йилнинг ноябрь ойида «De Facto» маркетинг агентлиги томонидан ўтказилган жамоатчилик фикрига биноан сўровда иштирок этган 300 нафар респондентларнинг 68\% “Family” ичимлик сувини NESTLE PURE LIFE® брендига тегишли деб хисоблаганлар. Шунингдек, “Ижтимоий фикр” жамоатчилик фикрини ўрганиш маркази томонидан ўтказилган ижтимоий сўров натижаларига кўра хам респондетларнинг аксарият қисми шундай фикрни билдиришган.

Ушбу холатларни суд жавобгар томонидан ичимлик сувини ишлаб чиқаришда, реклама қилишда ва тасарруф қилишда даъвогарнинг товар белгисига айнан ўхшаш, яъни қўллари юқорига кўтарилган одамлар тасвири (силуэти) ва марказдан таралаётган кўк-мовий нурлар фонидаги айлана график қисмлардан (элементлардан) иборат товар белгиси фойдаланилганлигини исботловчи далиллар сифатида бахолаган.

Шу сабабли биринчи инстанция суди даъвогарнинг аризасини қисман қаноатлантириб, жавобгарга ичимлик сувини ишлаб чиқаришда, реклама қилишда ва тасарруф қилишда қўллари юқорига кўтарилган одамлар тасвири (силуэти) ва марказдан таралаётган кўк-мовий нурлар фонидаги айлана график қисмлардан (элементлардан) иборат товар белгисидан фойдаланишни тўхтатиш мажбуриятини юклаш хақида хал қилув қарорини қабул қилган.

Айтиш жоизки, келажакда мамлакатимизда интеллектуал мулк объектлари билан боғлиқ бўлган низоларни хал этиш масаласи судлар фаолиятидаги долзарб масалалардан бирига айланиши тайин. Чунки, интеллектуал мулк хуқуқларининг бузилиши мавзуси бутун дунёда бўлгани каби бизнинг мамлакатимизда хам жиддий ижтимоий муаммога айланиб бормоқда. Бунинг бир нечта ўзига хос сабаблари бор, албатта.

Бинобарин, биринчидан, бу фақат ўзининг моддий манфаатлари хақидагина бош қотирувчи шахслар томонидан муайян янгилик яратиш учун хеч қандай сарфхаражат қилмасдан фойда ёки хатто қўшимча фойда олишнинг осон йўлидир. Иккинчидан, замонавий ахборот коммуникация технологиялари маълумотларни унинг муаллифи рухсатисиз ўзлаштириш, ўзига мос равишда ўзгартириш, кўпайтириш ва тарқатиш жараёнини ўта осон хамда арзон ишга айлантириб қўйди. Учинчидан, мамлакатимизда интеллектуал мулк объектлари ва уларга оид хуқуқларни таъминлашга қаратилган миллий қонунчилик базаси хали хамон лозим даражада такомиллашувга мухтож. Бу эса баъзи бир шахсларга ўзгалар томонидан яратилган интеллектуал мулк объектларидан ўз манфаати учун фойдаланиб қолиш имкониятларини беради, яъни улар ўз харакатларининг ахлоқ-одобга оид ва қонуний жихатлари хақида ўйлаб хам ўтиришмайди. Чунки, техник ривожланиш жадал суръатларда давом этмоқда ва у билан бирга турли-туман янги хуқуқбузарликлар хам содир этилмоқда. Қонунчилик нуқтаи назаридан эса бу 
ходисаларнинг барчасини қамраб олиш қийин, албатта. Шунинг учун ушбу масала бўйича хорижий мамлакатларнинг бой тажрибасини ўрганиш мухим саналади.

Хозирги кунга келиб дунёнинг кўплаб ривожланган мамлакатларида интеллектуал мулк объектларига доир хуқуқларни суд орқали химоя қилиш институти тобора кенгроқ қўлланилмоқда. Шунингдек, ушбу масалага доир халқаро шартномалар юзасидан вужудга келган низоларнинг судга тааллуқлиги, суд қарорларининг бажарилиши бўйича халқаро битимлар ва конвенциялар хам мавжуд.

Тахлиллар кўрсатадики, жахон мамлакатлари тажрибасида интеллектуал мулк объектлари билан боғлиқ ишларнинг судловга тааллуқлилиги масаласи асосан икки тарзда хал этилган. Жумладан, Бельгия, Бразилия, Венгрия, Гонконг, Дания, Исроил, Эрон, Испания, Италия, Канада, Голландия, Норвегия, Покистон, Панама, Руминия, Словения, Словакия, Жанубий Америка мамлакатлари, Финландия, Франция, Швеция каби давлатларнинг умумюрисдикция судлари тизимида интеллектуал мулкка доир ишларни кўриб чиқувчи махсус, яъни ихтисослашган суд таркиблари (двизионлар) ташкил этилган[5].

Австрия, Ирландия, Португалия, Швейцария ва Филлипинда эса интеллектуал мулкка доир низолар тижорат судлари томонидан кўриб чиқилади.

Бразилия, Колумбия, АҚШ ва Чилида интеллектуал мулк билан боғлиқ масалалар апелляция судларида кўрилади.

Австралия, Кения, Хитой, Янги Зелландия, Сингапурда эса ушбу масалага доир низоларни кўриб хал этувчи махсус трибуналлар ташкил этилган бўлиб, улар суд саналмайди.

Швейцариянинг Халқаро хусусий хуқуқ тўғрисидаги қонуни чет давлат хуқуқи мазмунини белгилашни судга юклайди, бунда суднинг тарафларга ёрдам сўраб мурожаат қилишига йўл қўйилади. Мулк билан боғлиқ низоларни кўриб чиқишда чет давлат хуқуқи мазмунини аниқлаш тарафларга юклатилиши мумкин.

Франция судларида чет давлат хуқуқи мазмунини аниқлаш мажбурияти тарафларга юклатилган. Шу билан бирга, судлар, агар чет давлат хуқуқи меъёрлари уларга маълум бўлса, ўз ташаббусига кўра ана шу меъёрларни хам қўллашлари мумкин.

Кўриниб турибдики, дунёнинг аксарият мамлакатлари суд тизимида патент судлари уларнинг анъанавий (классик) вариантида қарор топмаган. Бундай судлар асосан иккита давлатда, яъни Буюк Британия ва Германиядагина мумтоз шаклда мавжуддир.

Хусусан, Германияда патент судлари 1961 йилнинг 1 июлидан буён фаолият кўрсатиб келади. ГФР қонунлари интеллектуал мулк хуқуқи буйича доир ишларни кўриш жараёнида, умумий қоидага асосан, судларга низони хал этиш учун тарафлар тақдим этган далиллар билан чегараланиб қолмасдан, бошқа манбаларни хам жалб этиш ва судга маълум бўлмаган чет давлат хуқуқи мазмунини аниқлаш учун барча чораларни кўриш ваколатини беради. Чет давлат хуқуқий ex officio меъёрлари мазмунини белгилаш Венгрия, Австрия, Туркия, Италиянинг халқаро хусусий хуқуққа оид қонунларида хам назарда тутилган.

Таъкидлаш лозимки, интеллектуал мулк объектлари билан боғлиқ низоларни кўришга ихтисослашган алохида судларнинг ташкил этилганлиги 
низоларни сансалорликларсиз, қисқа муддатларда кўриб чиқилишига хамда қонуний, асосли ва адолатли суд қарорлари қабул қилинишига замин яратади

Одатда, интеллектуал мулк билан боғлиқ масалаларни кўриб чиқувчи махсус, яъни ихтисослашган судларнинг амалиётида асосан икки тоифадаги муаммо мавжуд бўлади. Биринчиси, субъектив омиллар билан боғлиқ бўлса, иккинчиси, объектив қийинчилар хисобланади. Чунончи, субъектив муаммолар қаторида судларда мазкур тоифадаги ишларнинг барчасини хам кўриб хал этиш бўйича тажрибанинг мавжуд эмаслигини айтиш мумкин. Кўп холатларда судга мурожаат этувчиларнинг аксарияти ўзининг хуқуқларини тўла англаб етмайдилар. Масалан, Россияда судга ариза берганлар уззларининг низоли мулкка эгалик хуқуқи расман тан олинганлигини тасдиқловчи хужжатларни тақдим қила олишмайди [6]. Бинобарин, амалдаги қонунчиликка кўра ўзининг хуқуқлари бузилган деб хисоблаган хар қандай шахс уни химоя қилиш учун судга мурожаат этиш хуқуқига эга. Холбуки, қонунчиликда барча интеллектуал мулк объектларига нисбатан хам муаллифлик хуқуқини рўйхатдан ўтказиш назарда тутилмаган.

Объектив омиллар сифатида судлар томонидан ушбу тоифадаги ишларни кўриб чиқишда муайян хуқуқий асоснинг мавжуд эмаслиги ёхуд тегишли қонун хужжатларининг лозим даражада такомиллашмаганлигини айтиш мумкин. Шу боис, бу борада ягона суд амалиётини яратиш имконияти мавжуд бўлмай қолмоқда.

Ўзбекистонда сўнгги йилларида амалга оширилган кенг кўламли суд-хуқуқ ислохотлари, жисмоний ва юридик шахсларнинг хуқуқ ва қонуний манфатларини химоя қилиш тизимини такомиллаштиришга, иқтисодиётда маъмурийбуйруқбозликка асосланган бошқарув тизимидан воз кечилиб, бозор ислохотлари босқичма-босқич амалга оширилгани интеллектуал мулк сохиблари учун кенг имкониятлар ва қулай шароитлар яратилишига хизмат қилмоқда. Бозор иқтисодиётига асосланган ижтимоий муносабатларнинг тобора ривожланиши, интеллектуал мулкнинг давлат ва жамият хаётидаги ахамияти ва ўрнининг кескин ошиб бораётганлиги республикамизда хам ителлектуал мулк билан боғлиқ низоларни кўриб чиқишга ихтисослашган судларнинг ташкил этиш заруратини келтириб чиқармоқда.

Шу сабабли, Ўзбекистон Республикаси Олий судида Интеллектуал мулк билан низоларни кўришга ихтисослашган судлов хайъатини ташкил этиш мақсадга мувофиқдир. Бу судлов хайъати томонидан айнан интеллектуал мулк билан боғлиқ низоларни қўриб чиқишнинг соддалаштирилган механизмлари ва тартиботларининг ишлаб чиқилиши натижасида судьяларнинг хам ихтисослашувига эришган бўлар эдик. Шунингдек, Ўзбекистон Республикаси Судьялар олий кенгаши хузуридаги Судьялар олий мактабида судьяларни интеллектуал мулк хуқуқига доир низоларни кўриш буйича қайта тайёрлаш хамда малакаларини ошириш тизимини йўлга қўйиш хамда бу борада Бутунжахон интеллектуал мулк ташкилоти ва Интеллектуал мулк агентлиги билан хамкорликни ривожлантириш мақсадга мувофиқдир.

Ўзбекистон Республикаси Президентининг “Интеллектуал мулк сохасида давлат бошқарувини такомиллаштириш чора-тадбирлари тўғрисида”ги 2019 йил 8 февралдаги Пқ-4168-сон қарорида мамлакатимизда интеллектуал мулк эгаларининг хуқуқларини суд тартибида химоя қилиш билан боғлиқ ислохотларни янада кучайтириш лозимлиги белгилаб берилганлиги хам юқорида баён этилган 
фикрларимиз асосли эканлигининг исботи сифатида қаралиши мумкин. Хусусан, мазкур қарорнинг 5-бандида интеллектуал мулкнинг самарали химоясини таъминлаш бўйича «Йўл харитаси тасдиқланган бўлиб унда интеллектуал мулк хуқуқини суд орқали химоя қилиш борасида жуда кўп ишларни амалга ошириш режалаштирилган. Жумладан, интеллектуал мулк хуқуқи сохасидаги маъмурий хуқуқбузарликлар тўғрисидаги ишларни кўриб чиқиш ва маъмурий жазо қўллаш хуқуқини адлия органларига тақдим этган холда, интеллектуал мулк объектларидан ноқонуний фойдаланганлик учун маъмурий жавобгарликни кучайтириш, интеллектуал мулк объектларидан ноқонуний фойдаланганлик учун жиноий жавобгарликни кучайтириш масаласини кўриб чиқиш ва шу билан бирга Ўзбекистон Республикаси Олий суди қошида Патент судини ташкил этиш масаласини ўрганиб чиқиб, асосланган таклифларни ишлаб чиқиш хам асосий вазифа этиб белгиланган.

Ушбу йўл харитасидаги вазифаларни амалга ошириш учун авваламбор интеллектуал мулк хуқуқини халқаро стандартлари нималардан иборат эканлигини, ушбу стандартларнинг барчаси Ўзбекстон Республикаси қонунчилигида имплементация қилинганлигини, халқаро стандартлар талаби даражасига келтириш учун миллий қонунчилигимизга қандай ўзгартириш ва қўшимчалар киритилиши лозимлигини белгилаб олиш зарур бўлади.

Фикримизча, энг аввало, республикамиз ФКнинг янги тахрири қабул қилинишида унинг амалдаги тахрири 2 , 8, 18, 27, 56, 81, 97, 99, 137, 169, 214, 695, $698,862,979,1007,1031-1111,1179,1180$-моддаларида белгиланган интеллектул мулк хуқуқи, муаллифлик хуқуқи, ихтироларга бўлган хуқуқ тўғрисидаги нормаларни халқаро стандартлар талабларига мослаштириш нуқтаи назаридан қайта кўриб чиқиш лозим.

Сўнгра, интеллектул мулк хуқуқи, муаллифлик хуқуқи, ихтироларга бўлган хуқуқ тўғрисидаги барча қонун хужатларини инвентаризация қилиш орқали уларни янги тахрирдаги ФКда белгиланадиган нормаларга мослаштириш лозим бўлади.

Шунингдек, Ўзбекистон Республикасининг Фуқаролик процессуал кодекси, Иқтисодий процессуал кодекси, Маъмурий суд ишларини юритиш тўғрисидаги кодексига хам интеллектул мулк хуқуқига оид низоларни кўришнинг ўзига хос хусусиятларини акс эттирувчи нормаларни жамлаган боб киритилиши мақсадга мувофиқ бўлади. Мазкур бобда қайд этилган тоифадаги ишлар бўйича даъво аризалар, аризалар, шикоятларга қўйиладиган талаблар, судга мурожаат қилиш муддатлари ва уларни кўриб чиқишнинг процессуал муддатлари, бу турдаги ишларни кўришнинг бошқа тоифадаги ишлардан фарқли бўлган жихатларини ёритиб берувчи барча холатларни ифодаловчи нормаларни назарда тутиш лозим бўлади.

Бундан ташқари, интеллектуал мулк хуқуқи сохасидаги маъмурий хуқуқбузарликлар учун маъмурий жавобгарликни, шунингдек интеллектуал мулк объектларидан ноқонуний фойдаланганлик учун жиноий жавобгарликни кучайтириш масалаларини хам кўриб чиқиш зарур.

Айни масалада қонунчилигимизни Россия Федерациясининг шунга ўхшаш қонунчилиги билан қиёслаш натижасида РФ Фуқаролик кодексининг мутлақ хуқуқлар бузилиши учун юридик шахслар ва хусусий тадбиркорларнинг 
жавобгарлиги хақидаги нормаси долзарб эканини англаб етиш мумкин. Унинг мазмуни эса қуйидагича:

«1253-модда. Мутлақ хуқуқлар бузилиши учун юридик шахслар ва хусусий тадбиркорларнинг жавобгарлиги

Агар юридик шахс интеллектуал фаолият натижаларига хамда индивидуаллаштирувчи воситаларга мутлақ хуқуқларнинг бир неча марта ёки қўпол равишда бузилишига йўл қўйса, суд мазкур Кодекснинг 61-моддаси 2бандига кура юридик шахснинг мутлақ хуқуқларнинг бузилишидаги айби тасдиқланган холатда прокурор талабига кураунинг тугатилиши хақида қарор қабул қилиши мумкин. Агар шундай хуқуқбузарликлар фуқаро томонидан у хусусий тадбиркор сифатида амалга ошираётган тадбиркорлик фаолияти мобайнида йўл қўйилган бўлса, қонунчиликда ўрнатилган тартибда суд қарори ёки хукми билан мутлақ хуқуқлар бузилишида унинг айби мавжуд бўлса, унинг индивидуал тадбиркор сифатидаги фаолияти тугатилиши мумкин».

Интеллектуал мулк хуқуқи билан боғлиқ турли хуқуқбузарликларнинг, хусусан, бу борадаги фирибгарлик, носоғлом рақобат, сохта муаллифликнинг олдини олиш, умуман айтганда, интеллектуал мулк хуқуқи билан боғлиқ жараён субъектларининг масъулиятини ошириш мақсадида бизнинг қонунчиликка хам шундай нормани жорий этиш мақсадга мувофиқ бўлар эди.

\section{Фойдаланилган адабиётлар}

1. Ўзбекистон Республикасининг Фуқаролик кодекси // Ўзбекистон Республикаси Олий Мажлисининг Ахборотномаси, 1996 й., 11-12-сон, 1-модда; .. 2016 й., 17-сон, 173-модда; 2017 й., 16-сон, 265-модда.

б.

2. Ўзбекистон Республикасининг Конституцияси. - Т.: “Ўзбекистон” 2018. - 76

3. [Электрон манба]: http://www.ima.uz/uz/services/sud-amaliyoti.

4. [Электрон манба]: https://gis.uz/uz/news/373 // “Ўзбеккино" миллий агентлиги махсулотларини ноқонуний тарқатган, муаллифлик хуқуқи ва турдош хуқуқларни бузган веб-сайт эгасига чора кўрилди.

5. Артамонова Е.М. к.ю.н., доцент кафедры судебной власти и организации правосудия факультета права НИУ ВШЭ // Специализированный суд по интеллектуальным правам в системе арбитражных судов // https://www.hse.ru/pubs/share/direct/document/69372829

6. Бабакулов 3.Қ. Товар белгиларининг фуқаролик-хуқуқий мақоми: назарий ва амалий масалалар // Монография. Масъул мухаррир: О.Оқюлов. - Т.: 2019. - Б.188. 